\title{
Diazotrophic bacteria respond to Saharan dust additions
}

\author{
Rebecca J. Langlois ${ }^{1,2, *}$, Matthew M. Mills ${ }^{1,3}$, Celine Ridame ${ }^{1,4}$, Peter Croot ${ }^{1,5}$ \\ Julie LaRoche ${ }^{1,2}$ \\ ${ }^{1}$ Helmholtz Centre for Ocean Research KiellGEOMAR, 24105 Kiel, Germany \\ ${ }^{2}$ Present address: Dalhousie University, Halifax, Nova Scotia B3H 4R2, Canada \\ ${ }^{3}$ Present address: Environmental Earth System Science, Stanford University, Stanford, California 94305, USA \\ ${ }^{4}$ Present address: LOCEAN-IPSL, Université Pierre et Marie Curie, 75252 Paris, France \\ ${ }^{5}$ Present address: National University of Ireland, Galway, Ireland
}

ABSTRACT: Three bioassay experiments were performed to study the effects of nutrient and Saharan dust additions on natural diazotrophic communities in the tropical North Atlantic Ocean. Samples for nucleic acid analysis were collected at the beginning and end of $48 \mathrm{~h}$ incubations. TaqMan probes specific to 7 diazotrophic phylotypes, viz. filamentous cyanobacteria (Trichodesmium spp.), unicellular cyanobacterial (UCYN) Groups A, B, and C, Gamma A and P Proteobacteria, and Cluster III, were used to quantify nifH DNA abundances. $\mathrm{N}_{2}$ fixation rates were measured in the same experiments using the ${ }^{15} \mathrm{~N}_{2}$ gas bubble injection method. $\mathrm{N}_{2}$ fixation was co-limited by $\mathrm{P}$ and Fe. Total nifH abundances increased relative to the control with additions of either Fe or P or both in combination. Additions of dissolved N, alone or in combination with phosphate, induced increases in UCYN-A and Gamma A nifH compared with the control. Saharan dust additions significantly stimulated fixation rates. Abundances of all cyanobacterial and Gamma A nifH phylotypes at least doubled after Saharan dust additions where surface water dissolved Fe concentrations were $<2 \mathrm{nmol}^{-1}$. Laboratory experiments with cultures of $T$. erythraeum demonstrated that dust addition promoted colony formation and the persistence of $T$. erythraeum biomass relative to cultures to which no Fe was added. Our results with both field and laboratory experiments indicate that Saharan dust positively affects diazotrophic phylotype abundances and changes $T$. erythraeum colony morphology.

KEY WORDS: Nutrient limitation - Nitrogen fixation • North Atlantic · Bioassay · Trichodesmium - UCYN-A · nifH $\cdot$ qPCR

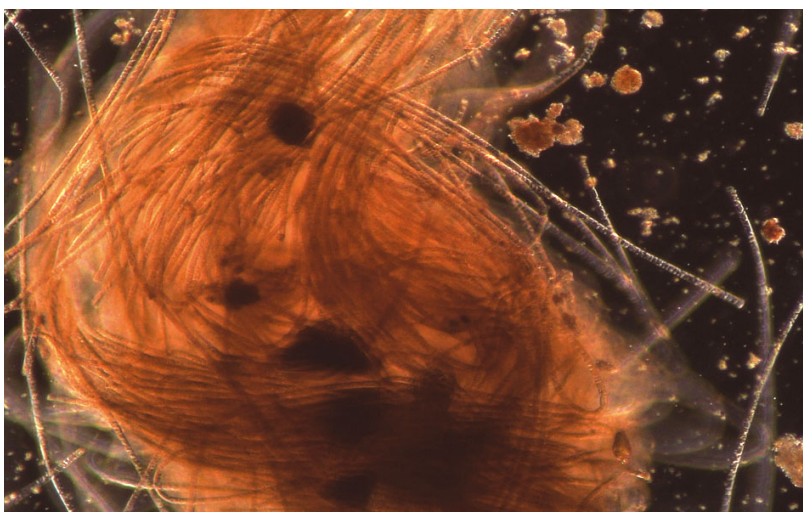

Saharan dust particles entrained in and around a radial colony of Trichodesmium erythraeum filaments.

Photo: R. J. Langlois, J. LaRoche

\section{INTRODUCTION}

Marine nitrogen inventory gain processes are biologically mediated. Fixed nitrogen enters the biogeochemical cycle through biological nitrogen $\left(\mathrm{N}_{2}\right)$ fixation, the reduction of atmospheric $\mathrm{N}_{2}$ gas to ammonium. Only a few specialized bacteria and Archaea, which contain the highly conserved protein nitrogenase, are able to fix $\mathrm{N}_{2}$. Due to the relatively low abundance of diazotrophs ( $\mathrm{N}_{2}$-fixing organisms), tracking their response to changes in environmental conditions has been problematic. Average diazotroph abundances under non-bloom conditions are

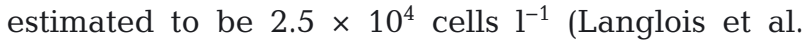
2008). In contrast, abundances of the common open- 
ocean cyanobacterial species Synechococcus and Prochlorococcus have been reported to be $5 \times 10^{7}$ and $1.3 \times 10^{8}$ cells $1^{-1}$, respectively, in the Atlantic Ocean (Davey et al. 2008). Although diazotroph abundances can reach concentrations above $10^{5}$ cells $1^{-1}$ (Church et al. 2008, Langlois et al. 2008, Moisander et al. 2010), it is not clear what conditions or environmental factors are needed for this to occur. In addition these estimates, made using quantitative polymerase chain reaction (qPCR) of the nifH gene (the marker gene that encodes nitrogenase reductase) and transcripts from diverse phylotypes, have shown that the relative abundance of various diazotrophs including unicellular and filamentous diazotrophs vary widely within and between oceanic basins (Church et al. 2008, Langlois et al. 2008).

Although information on the distributions of diazotrophs and $\mathrm{N}_{2}$ fixation in marine environments is accumulating, the environmental factors that control these distributions are still not well described (Langlois et al. 2008). Many environmental factors including availability of dissolved nutrients and atmospheric deposition of desert dust as a source of Fe and $\mathrm{PO}_{4}$ have been hypothesized to affect diazotrophic activity in the ocean (Mills et al. 2004, Lenes et al. 2005, Ridame et al. 2011). The low concentrations of inorganic nitrogen (N) found in oceanic environments should favor high diazotroph activity and abundance, but surface waters of oligotrophic oceans are often low or depleted in both $\mathrm{PO}_{4}$ and $\mathrm{Fe}$, which may ultimately control diazotroph distributions (Moore et al. 2009). There are few sources of $\mathrm{PO}_{4}$ in oceanic waters other than the remineralization of organic matter and atmospheric deposition (Mahowald et al. 2008), and thus the low availability of $\mathrm{PO}_{4}$ has been considered a constraint on $\mathrm{N}_{2}$ fixation in the North Atlantic (Wu et al. 2000, Mather et al. 2008). Diazotrophs are also hypothesized to be limited by Fe (Falkowski 1997, Karl et al. 2002) due to a relatively high requirement for the Fe-rich $\mathrm{N}_{2}$ fixing enzyme nitrogenase (Kustka et al. 2003). Diazotrophic phototrophs are further impacted by Fe availability because of the additional high Fe demand of the photosynthetic apparatus (Shi et al. 2007).

Aeolian inputs of desert dust supply the majority of Fe to the oligotrophic oceans (Jickells et al. 2005). The tropical North Atlantic Ocean is subjected to periodic dust storms originating in the Sahara, but indications of low Fe availability have been observed (Mills et al. 2004, Moore et al. 2006). Trichodesmium, the uncultured unicellular Group A cyanobacteria (UCYN-A), and other diazotrophic groups are abundant throughout dust-affected regions in the tropical and sub-tropical North Atlantic Ocean (Tyrrell et al. 2003, Capone et al. 2005), and abundances of nifH genes appear to be related to atmospheric dust deposition (Langlois et al. 2008).

We conducted 3 nutrient addition bioassay experiments in the sub-tropical North Atlantic Ocean to look at the effects of $\mathrm{NO}_{3}, \mathrm{PO}_{4}, \mathrm{Fe}$, all combinations of these, and Saharan dust additions on natural diazotrophic phylotype abundances using TaqMan qPCR. Primary production in the same bioassay experiments was shown to be N-limited (Davey et al. 2008), while $\mathrm{N}_{2}$ fixation was $\mathrm{Fe}$ and $\mathrm{PO}_{4}$ co-limited (Mills et al. 2004). Abundances of 7 diazotrophic phylotypes were detected and estimated, including filamentous cyanobacteria (Trichodesmium, Fil), UCYNA, Group B unicellular cyanobacteria (Crocosphaera, UCYN-B), Group C unicellular cyanobacteria (Cyanothece, UCYN-C), 2 gammaproteobacterial phylotypes (Gamma A and Gamma P), and a cluster III phylotype (CIII). To further investigate the effects of dust additions, cultures of $T$. erythraeum IMS101 were grown with or without iron and/or Saharan dust in the media, and changes in the photosynthetic efficiency, colony morphology, and nifH abundances were monitored.

\section{MATERIALS AND METHODS}

\section{Bioassay experiments}

Samples for molecular analysis were collected at the start and end ( $48 \mathrm{~h}$ ) of 3 bioassay experiments performed in Autumn 2002 during the Meteor 55 research cruise in the sub-tropical north Atlantic Ocean (Expts A,B described by Mills et al. 2004 and Expts B,C described by Davey et al. 2008). Station locations and initial conditions are given in Fig. 1 and Table 1. Experiments were conducted using trace metal clean techniques (Graziano et al. 1996). Surface seawater was pumped on-board using a Teflon diaphragm pump (Almatec) into a trace metal clean container. Seawater was collected in 601 carboys and then siphoned into acid-cleaned and seawater-rinsed 11 polycarbonate Nalgene bottles. Nutrients were added alone and in combination to final concentrations of $1.0 \mu \mathrm{mol} \mathrm{l} \mathrm{l}^{-1} \mathrm{NH}_{4} \mathrm{NO}_{3}(+\mathrm{N}), 0.2 \mu \mathrm{mol} \mathrm{l} \mathrm{l}^{-1}$ $\mathrm{NaH}_{2} \mathrm{PO}_{4}(+\mathrm{P})$, and $2.0 \mathrm{nmol}{ }^{-1} \mathrm{FeCl}_{3}(+\mathrm{Fe})$ to triplicate bottles under a laminar flow hood. Saharan dust was added alone at final concentrations of $0.5 \mathrm{mg} \mathrm{l}^{-1}$ (D1) and $2.0 \mathrm{mg} \mathrm{l}^{-1}$ (D2). Details on the chemical characterization of the dust were reported by Ridame \& Guieu (2002) and Mills et al. (2004). Bottles were 


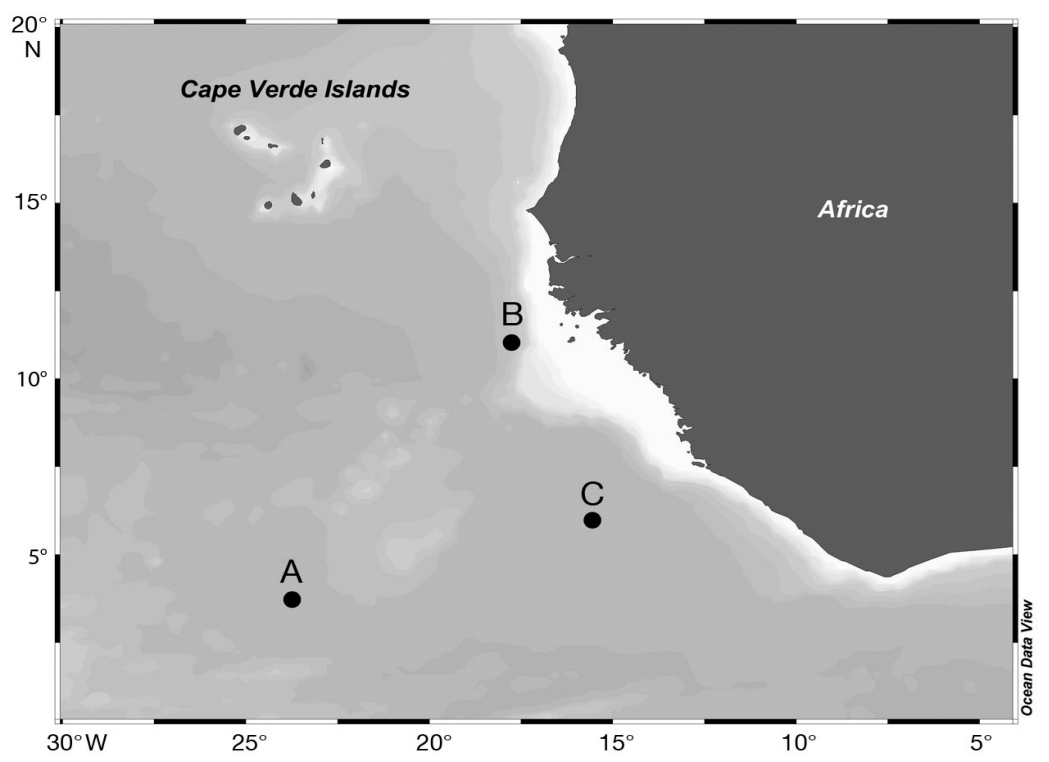

Fig. 1. North Atlantic Ocean, showing locations of the bioassay experiments (points A, B, and C) during the Meteor 55 cruise

then placed in incubators shaded to $20 \%$ of incident surface irradiance (range of 5 to $60 \mu \mathrm{mol}$ photons $\mathrm{m}^{-1}$ $\mathrm{s}^{-1}$ ) with blue filters (Lagoon Blue, Lee Filters \#172). Incubator water temperature was maintained with constant flowing seawater. Results of $\mathrm{N}$ and $\mathrm{CO}_{2}$ fixation rate measurements, chlorophyll a (chl a) concentrations, and changes in phytoplankton abundance and composition in response to the nutrient amendments can be found elsewhere (Mills et al. 2004, Davey et al. 2008). N fixation rates were likely underestimated (Mohr et al. 2010); however, this does not affect the conclusions drawn in this paper, as changes in rates relative to a control are being compared in bottles handled identically. Samples (1.5 l) for characterization of the initial diazotrophic community were collected during the experiment set-up and were filtered under low vacuum pressure (2 $\mathrm{kPa}$ ) onto $25 \mathrm{~mm}$ diameter, $0.2 \mu \mathrm{m}$ Durapore filters (Millipore). At the end of the $48 \mathrm{~h}$ incubation, the 300 to $800 \mathrm{ml}$ of water remaining in the triplicate $\mathrm{chl}$ a bottles was combined to make 1 sample per treatment and filtered as described above. Thus, the average response in the triplicate bottles was sampled. Filtrations took 1.5 to $2 \mathrm{~h}$, and afterwards filters were immediately frozen at $-80^{\circ} \mathrm{C}$ until extraction of nucleic acids in the laboratory.

\section{Culture experiments}

Non-axenic cultures of Trichodesmium erythraeum ISM101 were grown in YBCII media (Chen et al.
1996). Cultures were inoculated in sterile plastic tissue flasks under a laminar flow hood to limit bacterial and Fe contamination and grown under a 12:12 h light:dark cycle with an irradiance of $150 \mu \mathrm{mol}$ photons $\mathrm{m}^{-2} \mathrm{~s}^{-1}$. Cultures were gently shaken to re-suspend settled filaments and visually inspected daily. At the start of the experiment, $4 \mathrm{ml}$ of 1 stock culture in late exponential growth phase was used to inoculate 45 bottles (9 replicates for 5 treatments) of $40 \mathrm{ml}$ YBCII media. Fe concentrations were modified to $0 \quad\left(0 \mu\right.$ mol EDTA $\left.1^{-1}\right), 0.41$ $\left(2 \mu \mathrm{mol}\right.$ EDTA $\left.^{-1}\right)$, or $0.82 \mu \mathrm{mol}{ }^{-1}(4 \mu \mathrm{mol}$ EDTA $1^{-1}$ ). Additionally, a Saharan dust treatment (+Dust) was conducted in which $9 \mathrm{mg}$ of an uncharacterized $\leq 90 \mu \mathrm{m}$ sifted soil fraction, collected $20 \mathrm{~km}$ north-west of Agadir in Morocco (courtesy of Dr. A. Baker), was added to 18 bottles of YBCII media containing either 0 or $0.41 \mu \mathrm{mol} \mathrm{l}^{-1}$ Fe (9 bottles each) for a final dust concentration of $0.23 \mathrm{~g} \mathrm{l}^{-1}$. Saharan dust samples from 9 sites in a remote section of Morocco where the dust used in the culture experiments was collected were characterized by Guieu et al. (2002). This area is a known dust source region, and the soil collected here is typical of aerosols entrained under high winds and blown out to sea (Guieu et al. 2002). There is no single dust source, and even aerosols collected at sea show variation (Shi et al. 2011). Three bottles from each treatment were used for biomass analysis, 3 for quantifying nifH abundance after $60 \mathrm{~h}$, and 3 for quantifying nifH abundance after $132 \mathrm{~h}$. The entire culture volume (44 ml) was used for estimating gene abundances. Starting inoculation amounts (4 $\mathrm{ml}$ of stock culture) were filtered in triplicate for initial $(0 \mathrm{~h})$ measurements of nifH abundances. The experiment was repeated 3 times and showed replicable outcomes in visual growth and changes in colony morphology. Samples for nucleic acid extraction and qPCR analysis were collected for only one of the experiments.

\section{DNA extraction, cDNA synthesis, nifH amplification, and cloning}

DNA from the bioassay experiments was extracted using the Qiagen DNeasy Plant extraction kit. Filters were broken up by holding the cryo-tube containing the filter in liquid nitrogen for $30 \mathrm{~s}$ and then using a sterile pipette tip as a pestle. Lysis buffer was applied directly to the filter pieces, and extraction followed 


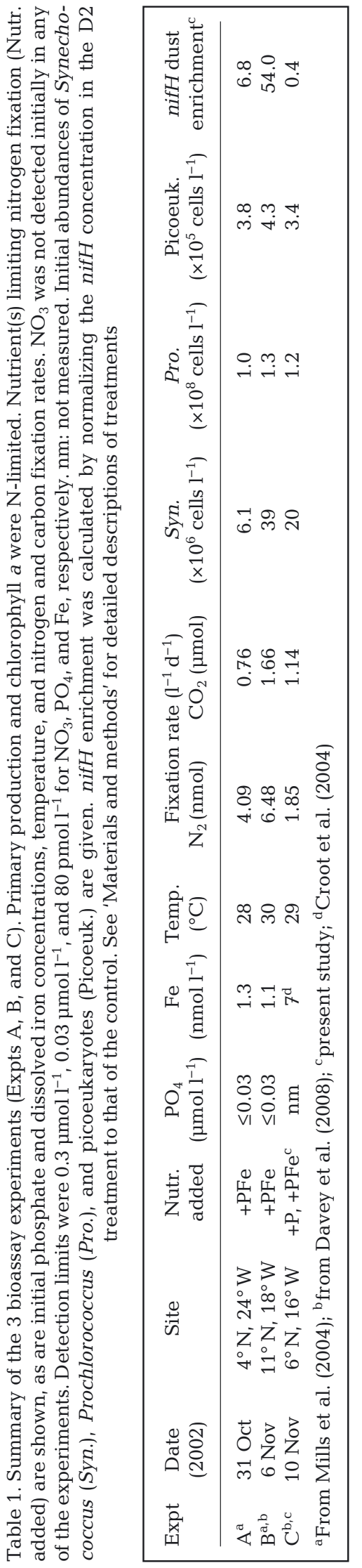

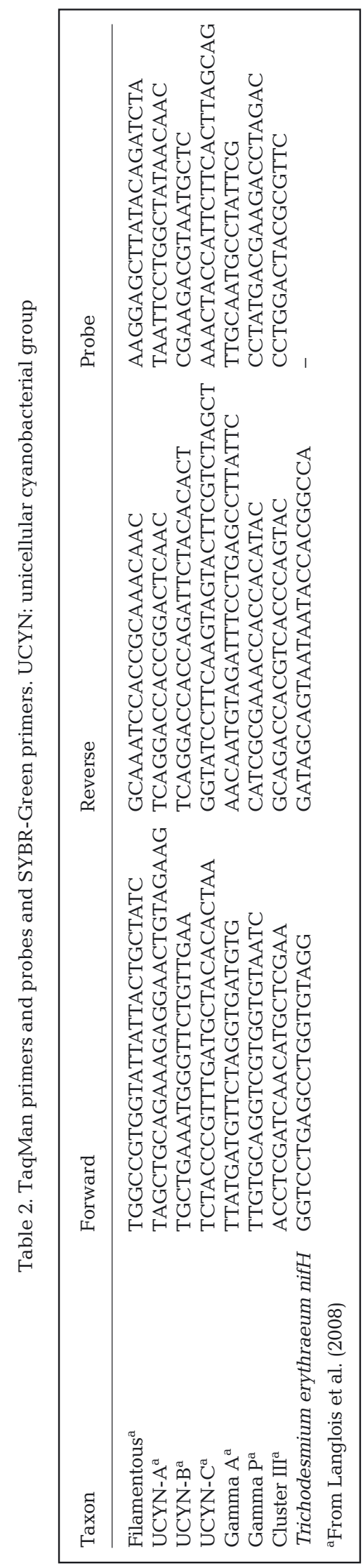

according to the manufacturer's instructions. RNA and DNA were simultaneously extracted from the culture experiment samples using the Qiagen All-Prep DNA/RNA extraction kit and the same sample preparation steps described above. DNA and RNA were eluted into $50 \mu \mathrm{l}$ PCR grade water. Amplification and cloning of nifH was performed as described by Langlois et al. (2005), using the nested PCR protocol and nifH primers described by Zani et al. (2000). Bands of the correct size (354 bp) from the control, +PFe, and dust treatments were inserted into the Topo TA vector and into Top 10 chemically competent Escherichia coli cells according to the manufacturer's instructions (Invitrogen). Clones were screened for inserts using T3 and T7 primers, and screened inserts of the correct size were sequenced. nifH sequences from the initial microbial populations have already been published (Langlois et al. 2005).

DNA and RNA concentrations were measured using the Picogreen DNA and Ribogreen RNA quantitation kits (Molecular Probes), respectively. RNA samples from the culture experiment were transcribed to cDNA using the Quanti-Teq cDNA synthesis kit and DNase digest step (Qiagen) according to the manufacturer's instructions. Abundances of filamentous (Trichodesmium spp., Fil), Group A unicellular (UCYNA), Group B unicellular (UCYN-B), Group C unicellular (UCYN-C), Gamma A CIII and Gamma P proteobacterial, and CIII nifH DNA were estimated in the bioassay samples using the specific TaqMan probe and primer sets described by Langlois et al. (2008; Table 2). Plasmid standards for each primer/ probe set (Langlois et al. 2008) were used, and all samples were run with the same set of standards. Primer efficiencies $\left(E=10^{-1 / \text { slope }}-1\right)$ were $92 \%$ for Fil $\left(\mathrm{R}^{2}=0.996\right), 92 \%$ for UCYN-A $\left(\mathrm{R}^{2}=\right.$ $0.994), 94 \%$ for UCYN-B $\left(R^{2}=0.993\right)$, $79 \%$ for UCYN-C ( $\left.\mathrm{R}^{2}=0.999\right), 96 \%$ for Gamma A ( $\left.\mathrm{R}^{2}=0.991\right), 86 \%$ for Gamma $\mathrm{P}\left(\mathrm{R}^{2}=0.999\right)$, and $91 \%$ for CIII $\left(\mathrm{R}^{2}=\right.$ 
0.997). TaqMan master mix (Applied Biosystems) was used and samples were run in an ABI Prism 7000 Real-Time PCR cycler, with the default program set to 45 cycles. Every experimental sample was run in triplicate, while standards and no-template controls (NTCs) were run in duplicate. No amplification was observed in NTCs.

Abundances of Trichodesmium erythraeum nifH in culture experiment samples were estimated using the primer set $T$. erythraeum nifH (Table 2). All DNA, cDNA, and RNA samples from culture experiments were run in triplicate using SYBR-Green Master Mix (Invitrogen), and the default thermocycler program was modified as follows: the activation time was reduced to $2 \mathrm{~min}$ and the annealing time to $30 \mathrm{~s}$. The Fil standard was used to quantify the number of copies in these reactions $\left(E=97 \%, \mathrm{R}^{2}=0.998\right)$. No amplification was observed in NTC and RNA control reactions, indicating that all reagents were clean and that there was no contaminating DNA in cDNA reactions. Quantities of nifH phylotypes in the qPCR reactions were calculated using the ABI Sequence Detection Software (v. 1.2.3) with RQ application.

\section{qPCR detection limits and statistical analyses}

The average cycle threshold $(\mathrm{Ct})$ deviation for all samples was $0.63 \mathrm{Ct}$ with a mean coefficient of variation of $1.6 \%$ (range 0.02 to $4.63 \%$, median $1.7 \%$ ). These values were nearly identical for all primer/ probe sets. The detection limit of qPCR analysis is 1 gene copy per reaction, which corresponds to a $\mathrm{Ct}$ value of 39 for primer/probe sets UCYN-B, Gamma $\mathrm{A}$, and Gamma P or a $\mathrm{Ct}$ value of 40 for the remaining sets. As different sample volumes were filtered for the field data set, the actual detection limit for the bioassay sample set varied from 33 copies $\mathrm{l}^{-1}$ (1.5 l filtered) to 170 copies $^{-1}$ (0.3 l filtered); however, the majority $(75 \%)$ of the samples had a detection limit of 100 copies $l^{-1}$. The detection limit for the culture experiment samples was higher $\left(1250\right.$ copies $\left.\mathrm{l}^{-1}\right)$ due to the smaller sample volume filtered. Samples which amplified at Ct values of $>38$ or $>39$ ( 1 cycle less than the $\mathrm{Ct}$ for $1 \mathrm{copy}$ ) in at least duplicate reactions were called 'detectable, but not quantifiable' and are noted in the text. Values of $p<0.05$ were considered significant. Due to limited experimental water resources, it was not possible to collect replicate samples for nucleic acid analysis. Instead, multiple experiments were conducted. Analysis of triplicate cultures showed small variations in abundances, indicating that the extraction and analysis techniques are highly reproducible. Relative change was calculated as (abundance treatment $\times$ abundance $_{\text {control }^{-1}}$ ) -1 . Statistical analyses were performed using Statistica 8.0. The nitrogen fixation rates and laboratory experiment qPCR data were analyzed using a 1-way analysis of variance (ANOVA) with a Fisher LSD post hoc test.

\section{RESULTS}

\section{Diazotrophic community composition in bioassay experiments}

All samples from bioassays experiments conducted at 3 sites in the tropical North Atlantic Ocean (Table 1, Fig. 1) were tested for the presence and abundance of 7 diazotrophic phylotypes. Fil (which detects both Trichodesmium and Katagnymene), UCYN-A, UCYN-B, UCYN-C, and Gamma A phylotypes were quantifiable in at least 1 bioassay experiment. The CIII phylotype was not detected in any samples, and the Gamma P phylotype was detected in only the D2 treatment of all experiments, but was not quantifiable. Analysis of clone libraries from the various treatments showed that no new phylotypes were stimulated by the nutrient/dust additions and that the qPCR probes targeted all dominant diazotrophic phylotypes (data not shown). The diversity of the diazotroph community decreased from west to east as seen by the number of phylotypes detected by qPCR; 5 were quantifiable in Expt A, while only 2 were quantifiable in Expt C. The Fil and UCYN-A phylotypes were detected in all experiments and were most abundant.

Trends in both total nifH abundances and $\mathrm{N}_{2}$ fixation rates were observed in the bioassay experiments (Fig. 2). $\mathrm{N}_{2}$ fixation rates were co-limited by $\mathrm{P}$ and $\mathrm{Fe}$ in all 3 experiments $(p<0.05)$, as previously determined by Mills et al. (2004). Despite this clear association in $\mathrm{N}_{2}$ fixation rates, total nifH abundances (the sum of all phylotypes detected) were higher in $+\mathrm{PFe}$ than the control in Expt $\mathrm{C}$ only. Dust additions nearly doubled and tripled $\mathrm{N}_{2}$ fixation rates relative to the control in Expts A and B, respectively (Mills et al. 2004). In contrast, Saharan dust additions increased total nifH concentrations by over an order of magnitude in Expts A and B with D2, the higher dust concentration, causing an even larger increase in abundances than D1 in Expt A.

A different response was elicited in Expt C, where $\mathrm{N}_{2}$ fixation rates were the lowest. In this experiment, additions of $\mathrm{P}$ and $\mathrm{PFe}$ increased $\mathrm{N}_{2}$ fixation rates to statistically similar values, while $\mathrm{N}_{2}$ fixation rates in 

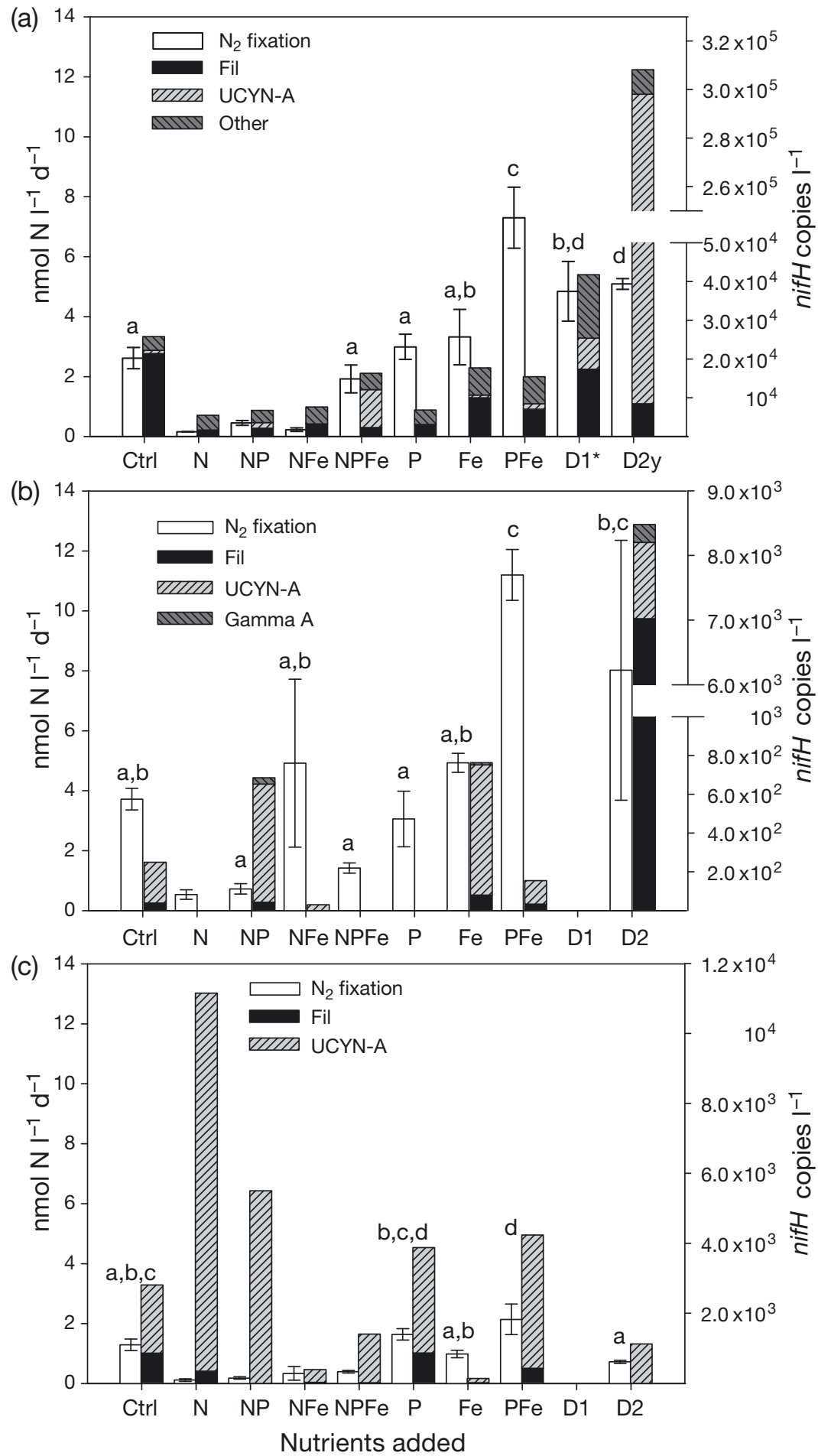

Fig. 2. Average $( \pm \mathrm{SE}) \mathrm{N}_{2}$ fixation rates $\left(\mathrm{nmol} \mathrm{N} \mathrm{^{-1 }} \mathrm{d}^{-1}\right)$ and abundances of nifH phylotypes (nifH copies $\mathrm{l}^{-1}$ ) detected in bioassay: (a) Expt $\mathrm{A}$, (b) Expt B, (c) Expt C. Fixation rates for Expts A and B have been previously published (Mills et al. 2004) and have been re-plotted here. Letters identify mean $\mathrm{N}_{2}$ fixation rates that are higher than or equal to the control (Ctrl) rate, and same letters denote means which are not statistically different from one another. Note that not all phylotypes were detectable in each experiment. * Only Expt A had the D1 (Dust) treatment. See 'Materials and methods' for detailed descriptions of treatments
D2 were statistically similar to rates measured in the control, $+\mathrm{Fe}$, and $+\mathrm{P}$ treatments. Saharan dust additions did not impact diazotroph phylotype abundances in this experiment either. The initial Fe concentrations measured in this experiment were much higher $(20$ nmol $\left.\mathrm{l}^{-1}\right)$ than in Expts $A$ and $B(<2$ nmol $\mathrm{l}^{-1}$ ), which may have been due to contamination during sampling for dissolved Fe. Water samples collected from an independent group showed concentrations of $7 \mathrm{nmol} \mathrm{l}^{-1}$ (Croot et al. 2004), still much higher than in Expts A and B. Surface waters had low salinity at this site due to heavy rainfall from the Intertropical Convergence Zone which also contained Fe and N (Baker et al. 2007), indicating that the diazotrophic community may not have been Fe-stressed at this site. Surprisingly additions of $\mathrm{N}$ alone, and in combination with $\mathrm{P}(+\mathrm{NP})$, resulted in increases of UCYN-A abundances to 1.1 $\times 10^{4}$ and $5.5 \times 10^{3}$ nifH copies $\mathrm{l}^{-1}$, respectively, from $2.0 \times 10^{3}$ nifH copies $1^{-1}$ in the control. In fact, UCYN-A abundances appeared to increase in the +NP treatment in all 3 experiments, although dust additions resulted in the largest increases in UCYN-A nifHDNA.

A closer look at Expt A, where diazotrophic phylotypes were most abundant, revealed complexity among the individual phylotype responses to nutrient amendments (Fig. 3). Although the relative change in total abundances to the control was negative in all treatments except for dust amendments (Fig. 3a), increases in abundances were observed when each group was studied individually. The relative change of Fil to the control was negative in Expt A (Fig. 3b); however, abundances in the $+\mathrm{Fe},+\mathrm{PFe}, \mathrm{D} 1$ and D2 treatments were at least double those measured in treatments where $\mathrm{N}$ was added $\left(>7 \times 10^{3}\right.$ versus $<3.2 \times 10^{3}$ nifH copies $1^{-1}$, Fig. 2a). The same trend in abundances measured in the $+\mathrm{Fe},+\mathrm{PFe}, \mathrm{D} 1$ and D2 treatments compared to $+\mathrm{N}$ treatments was observed in the UCYN-C group (Fig. 3d), and the relative change to the 

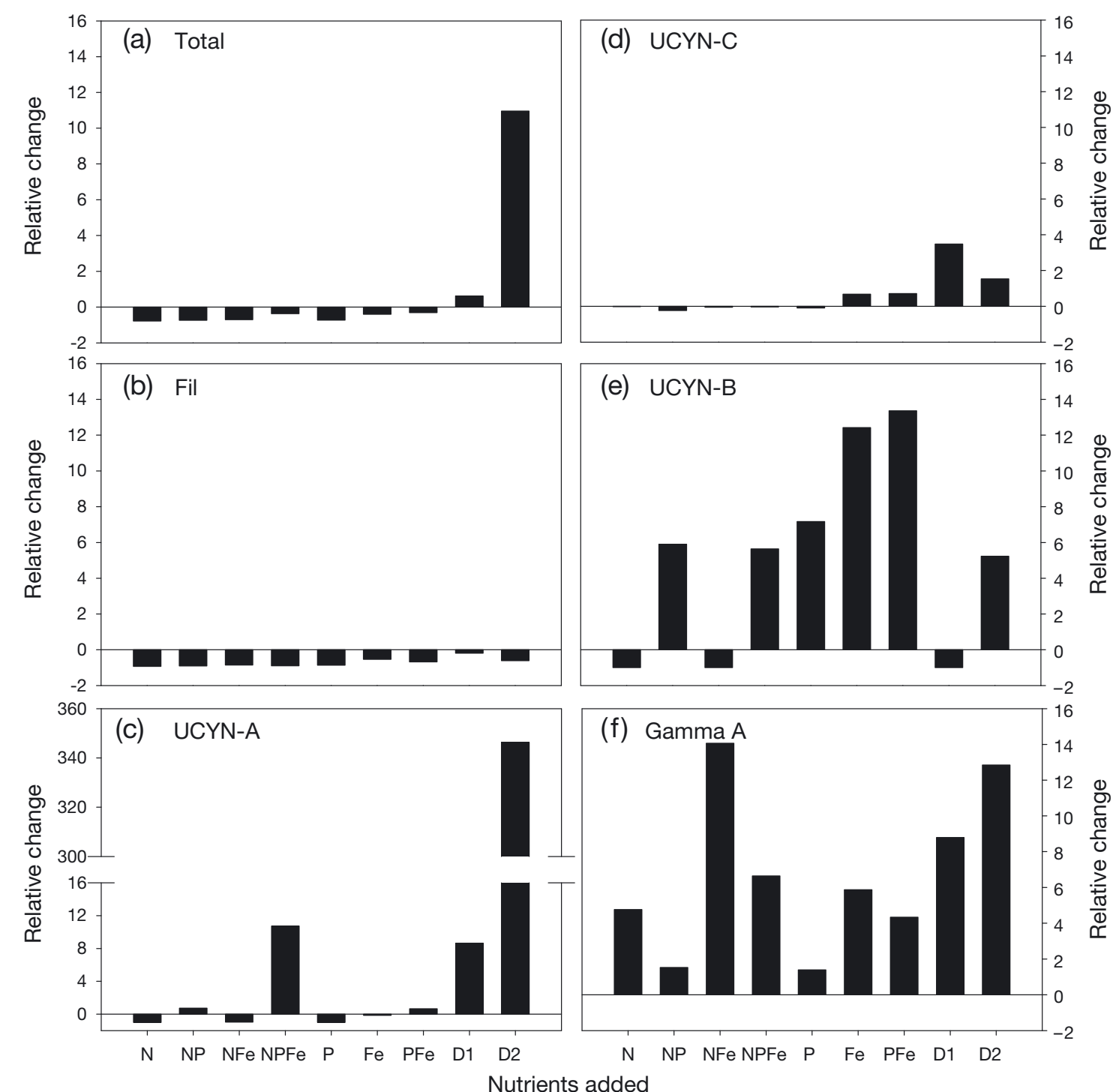

Fig. 3. Relative changes in phylotype concentrations with respect to the control in Expt A. Individual graphs are lettered in order of decreasing abundances. (a) The total is the sum of all phylotypes detected in a treatment. (b) Filamentous (Fil) was the dominant phylotype detected in nearly all treatments. (c) Unicellular cyanobacterial group A (UCYN-A) was dominant in $+\mathrm{NPFe}$ and D2, and (d) UCYN-C was the next most abundant phylotype. (e) UCYN-B and (f) Gamma A had roughly the same concentrations. Note the different $y$-axis scale in (c). See 'Materials and methods' for detailed descriptions of treatments

control was positive for this group. In contrast, UCYN-B abundances increased with additions of $\mathrm{P}$ and $\mathrm{Fe}$ alone or combined and sometimes with $\mathrm{N}$ (Fig. 3e). Interestingly, UCYN-A (Fig. 3c) and Gamma A (Fig. 3f) abundances were positively influenced by additions of $\mathrm{N}$ either alone or in combination with other dissolved nutrients. Combined, these results indicate that diverse diazotrophic phylotypes respond differently to changes in nutrient concentrations.

Comparisons of changes in picophytoplankton (Synechococcus, Prochlorococcus, and picoeukaryotes) relative abundances in the dust treatments were made to investigate the possibility that the
Saharan dust additions may have been toxic to the phytoplankton community and showed variability between experiments (Fig. 4a). Dust additions had an increasingly negative effect on Synechococcus and Prochlorococcus abundances, but an increasingly positive effect on picoeukaryotes moving eastward. Interestingly, the positive effect of Saharan dust on UCYN-A abundances decreased from Expts A to C (Fig. 4d). The effect of dust on picophytoplankton abundances was clearly variable and probably due to an environmental variable not constrained in this study, as no other treatment produced such a pattern in relative abundances of this group. 


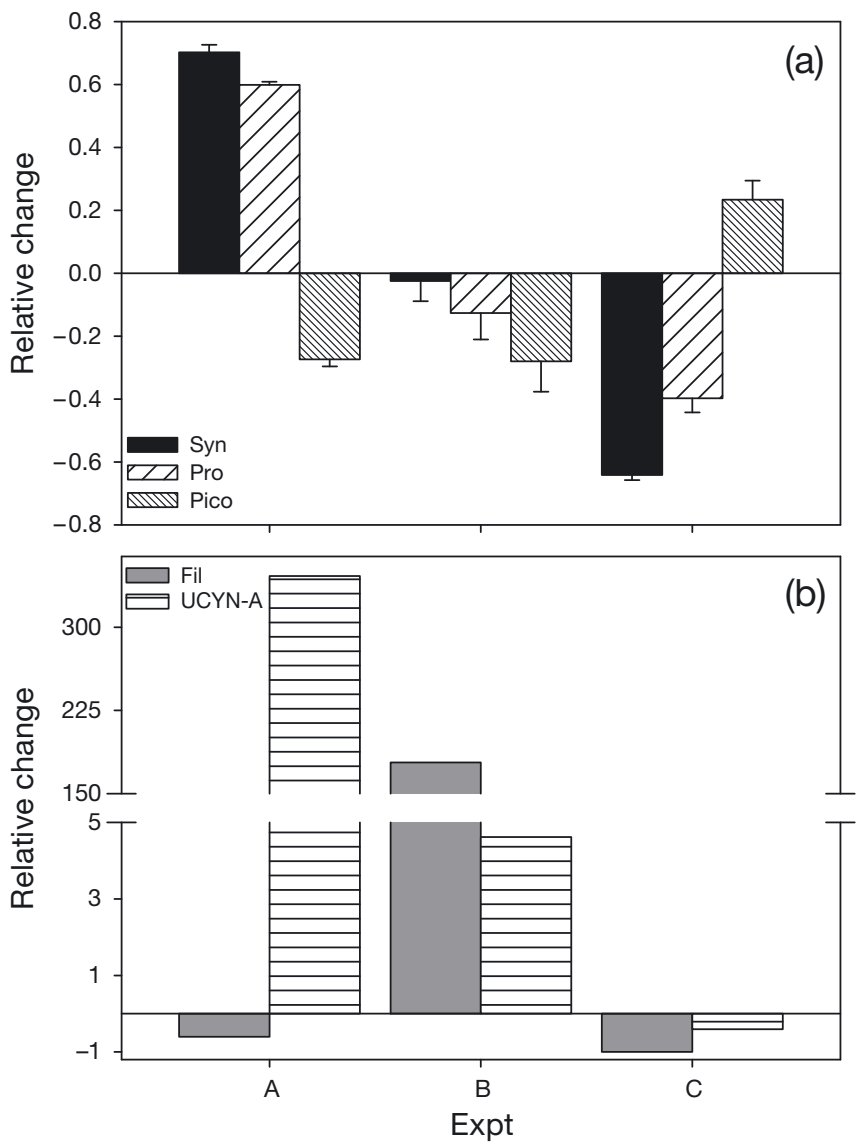

Fig. 4. Relative changes in abundance of (a) picophytoplankton cells and (b) dominant phylotypes in the D2 treatment compared to the respective control. Mean abundances of Synechococcus (Syn), Prochlorococcus (Pro), and picoeukaryotes (Pico) as measured by analytical flow cytometry are shown. Error bars in (a): SE ( $=3)$ Abundances of filamentous (Fil) and UCYN-A nifH are shown in (b). See 'Materials and methods' for detailed descriptions of treatments

\section{Effects of Saharan dust on Trichodesmium cultures}

Culture experiments where T. erythraeum was grown in media without $\mathrm{Fe}\left(0.0 \mu \mathrm{mol} \mathrm{Fe}{ }^{-1}\right)$, Fe concentrations of normal YBC II media $\left(0.41 \mu \mathrm{mol} \mathrm{Fe}^{-1}\right)$, Saharan dust $\left(0.0 \mu \mathrm{mol} \mathrm{Fe} \mathrm{l}^{-1}+\right.$ Dust and $0.41 \mu \mathrm{mol} \mathrm{Fe}$ $\mathrm{l}^{-1}+$ Dust), and twice the Fe concentration of YBCII

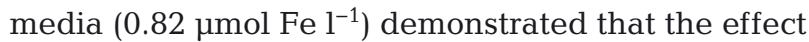
of dust on nifH abundances observed in field samples can be partially replicated in laboratory cultures. T. erythraeum colony morphology was different in the various treatments (Fig. 5). No colonies were observed in $0.0 \mu \mathrm{mol} \mathrm{Fe} \mathrm{l}^{-1}$ bottles after $60 \mathrm{~h}$, and within $48 \mathrm{~h}$ of the transfer into Fe-free medium, filaments became very short, thick, and dark red. In contrast, some colonies formed and persisted until the end of the experiment (132 h) in the dust-only bottles.
Large radial colonies (puffs) were observed in all dust-amended bottles after $24 \mathrm{~h}$, while only filaments were observed in bottles with just Fe added.

Changes in biomass were followed by estimating nifH DNA and cDNA at 60 and $132 \mathrm{~h}$ using TaqMan qPCR (Fig. 6). At $60 \mathrm{~h}$, the highest nifH abundances

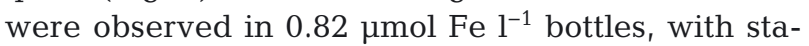
tistically similar abundances for $0.41 \mu \mathrm{mol} \mathrm{Fe} \mathrm{l}^{-1}$ +Dust bottles. Abundances in $0.41 \mu \mathrm{mol} \mathrm{Fe} \mathrm{l}^{-1}$ bottles were lower and statistically different from $0.82 \mu \mathrm{mol} \mathrm{Fe}{ }^{-1}$ bottles but not from the $0.41 \mu \mathrm{mol}$ $\mathrm{Fe}^{-1}$ +Dust bottles. By $132 \mathrm{~h}$, these 3 treatments contained similar amounts of nifH DNA. A small decrease in the amount of nifH over the $7 \mathrm{~d}$ in the $0.0 \mu \mathrm{mol} \mathrm{Fe} \mathrm{l}^{-1}+$ Dust treatment was observed, while nifH decreased by 2 orders of magnitude in $0.0 \mu \mathrm{mol}$ Fe $\mathrm{l}^{-1}$ media.

The abundances of nifH cDNA over time were more variable. The quantity of nifH cDNA decreased in all treatments after $60 \mathrm{~h}$. The largest decrease occurred in the $0.0 \mu \mathrm{mol} \mathrm{Fe} \mathrm{l}^{-1}$ treatment where nifH abundances decreased by over 2 orders of magnitude; in fact, nifH abundances decreased to undetectable levels in 2 of the triplicate bottles by the end of the experiment. nifH cDNA abundances in the $0.0 \mu \mathrm{mol} \mathrm{Fe} \mathrm{l}^{-1}+$ Dust treatment also declined, although they were still significantly higher $(p<0.05)$ than in the $0.0 \mu \mathrm{mol} \mathrm{Fe} \mathrm{l}^{-1}$ treatment. These results suggest that Trichodesmium erythraeum was able to access and utilize iron from Saharan dust for maintaining its biomass.

\section{DISCUSSION}

\section{Comparison of experimental sites}

Although the distribution of diazotrophs, especially that of Trichodesmium, has often been observed to be correlated with atmospheric mineral dust deposition (Tyrrell et al. 2003, Mahaffey et al. 2005, Moore et al. 2009), until now no studies have looked at how diazotrophs are directly affected by dust at the molecular level. The bioassay experiments presented here demonstrate that the abundance of diazotrophic organisms increases, as estimated by nifH gene copy numbers, with variable nutrient additions, while $\mathrm{N}_{2}$ fixation is $\mathrm{P}$ and Fe co-limited. Saharan dust additions caused large increases in nifH concentrations in the 2 experiments that also showed stimulation of $\mathrm{N}_{2}$ fixation rates in response to the dust amendments.

While dust additions increased the abundance of diazotrophic phylotypes in bioassay Expts A and B, 

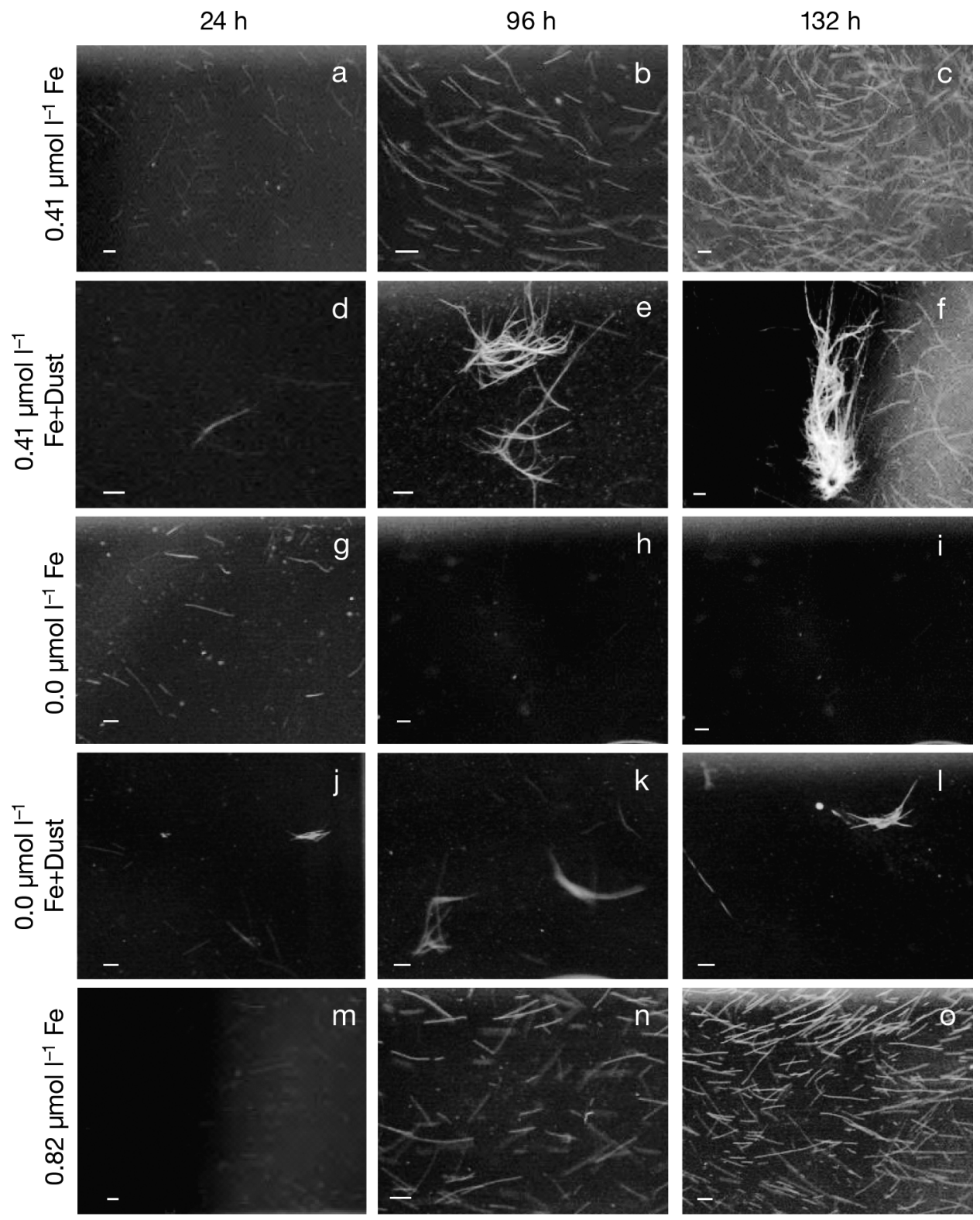

Fig. 5. Trichodesmium erythraeum. Changes in morphology during growth on dissolved iron and/or Saharan dust. T. eryth-

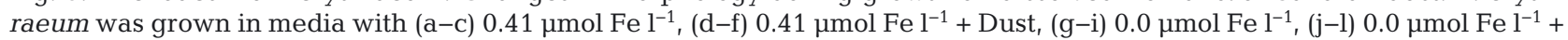

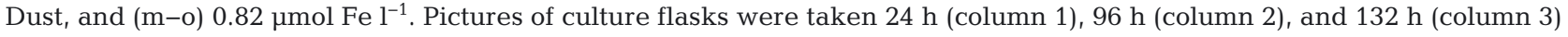
after the start of the experiment. No colonies or filaments were observed in the $0.0 \mu \mathrm{mol} \mathrm{Fe} \mathrm{treatment} \mathrm{(h} \mathrm{and} \mathrm{i)} \mathrm{after} 24 \mathrm{~h}$.

Scale bars $=90 \mu \mathrm{m}$

the $+\mathrm{P}_{1}+\mathrm{PFe},+\mathrm{N}$, and $+\mathrm{NP}$ additions resulted in high nifH concentration increases in Expt $\mathrm{C}$, where dust amendments had no effect. Like Expts A and B, primary productivity was N-limited in Expt C (Davey et al. 2008), and $\mathrm{N}_{2}$ fixation was $\mathrm{P}$ and Fe co-limited. In contrast to Expts A and B, the initial Fe concentration of Expt C was much higher (Table 1). Fe concentrations measured during the same cruise increased eastwardly across the Atlantic Ocean (Croot et al.
2004). Also unlike Expts A and B, Fe additions did not result in any increases in phylotype abundance above control abundances at site $\mathrm{C}$ (see Fig. 1). Instead, $\mathrm{P}$ and N/NP additions resulted in higher Fil and UCYN-A concentrations, respectively. P additions resulted in statistically similar $\mathrm{N}_{2}$ fixation rates to $+\mathrm{PFe}$. This indicates that diazotrophs may have been more P-stressed at Site C as opposed to Festressed at the other 2 stations. 

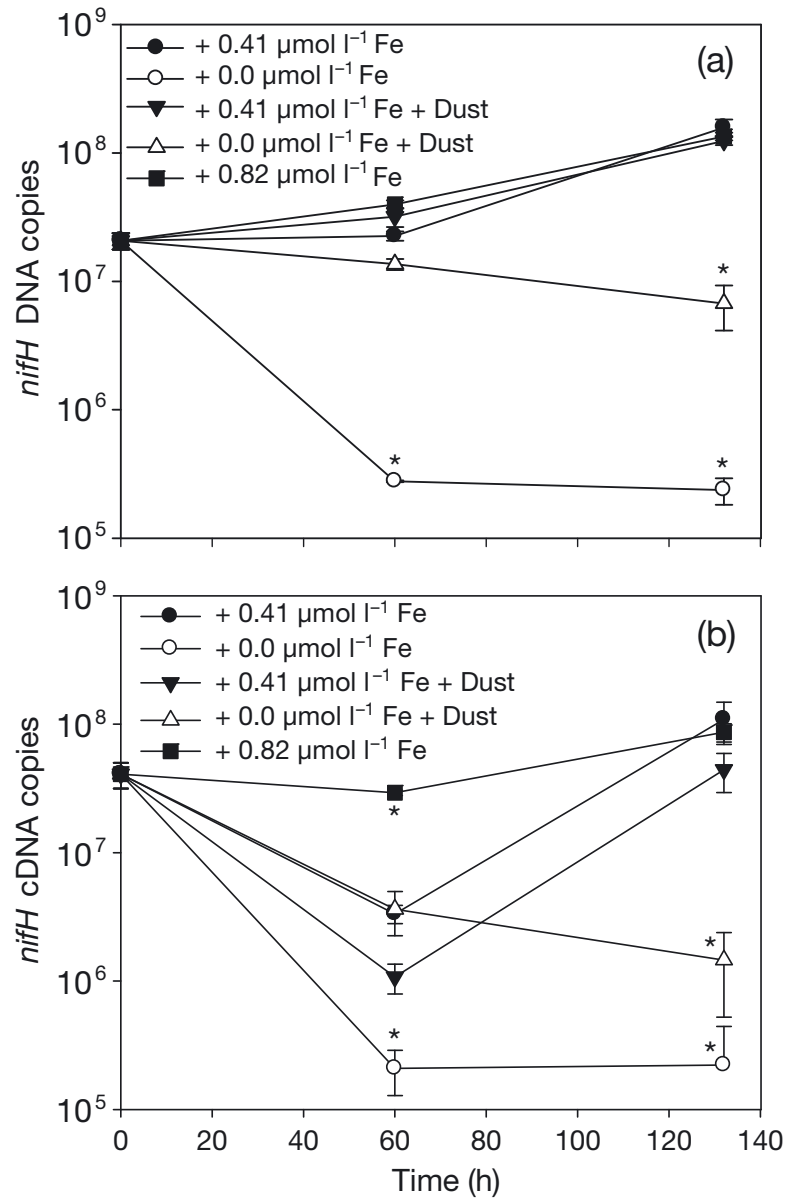

Fig. 6. Trichodesmium erythraeum. Changes in (a) nifH DNA and (b) nifH cDNA copy numbers during growth on dissolved iron and/or Saharan dust. Average $( \pm \mathrm{SE})$ measurements from triplicate incubation bottles are shown. See 'Materials and methods' for detailed descriptions of treatments. ${ }^{*}$ Values which are significantly different $(p<0.05)$ from all other treatments per time point

\section{Effects of nutrient additions}

A disparity was observed between the nutrient additions which resulted in increases in $\mathrm{N}_{2}$ fixation rates and diazotroph phylotype abundances. In Expt $\mathrm{C}, \mathrm{N}_{2}$ fixation rates were significantly enhanced only by the addition of $\mathrm{P}$ or $\mathrm{PFe}$, but maximum increases in phylotype abundances were seen with $\mathrm{N}$ and $\mathrm{P}$ additions. This could be explained by the role each nutrient plays in the cell. $\mathrm{P}$ is used by cells for growth and division and is found in nucleic acids, adenosine triphosphate, and phospholipids. Fe is a major component of enzymes, including nitrogenase. Increases in $\mathrm{P}$ and $\mathrm{Fe}$ could raise the potential for a diazotroph to carry out $\mathrm{N}_{2}$ fixation. $\mathrm{N}$ is found in nucleic acids and metabolic compounds, which is important for growth and division. Previously pub- lished results from the same bioassay experiments showed that carbon fixation was $\mathrm{N}$-limited but that cell growth was $\mathrm{N}$ and $\mathrm{P}$ co-limited (Davey et al. 2008). Perhaps the $N$ and $P$ additions stimulated the diazotrophic organisms in Expt $\mathrm{C}$ to either divide or make extra copies of their genomes, which would be detected as an increase in nifH abundances with qPCR. The combined $\mathrm{P}$ and Fe amendments stimulated diazotrophs to fix $\mathrm{N}_{2}$, which would not necessarily correlate with an increase in nifH DNA, as the nifH DNA is just the molecular blueprint for $\mathrm{N}_{2}$ fixation. It is more logical that nifH expression, which occurs during or just previous to $\mathrm{N}_{2}$ fixation, and $\mathrm{N}_{2}$ fixation rates could be correlated, but nifH cDNA was not looked at in this part of the study.

Cultured marine diazotrophs have relatively slow growth rates. Doubling rates ranging from $0.6 \mathrm{~d}^{-1}$ for Crocosphaera to $0.3 \mathrm{~d}^{-1}$ for Trichodesmium, or 40 to $80 \mathrm{~h}$, respectively, have been published (Raven 2012). Although the length of the incubations was only $48 \mathrm{~h}$, this was sufficient time for the cells to respond at the DNA replication level and for growth to occur. In many treatments, nifH copy numbers increased multiple-fold. DNA gene copy abundances are often used as a proxy for cell abundances, but some cells may have multiple copies of a gene per genome or have multiple genomes per cell, complicating the interpretation of qPCR-based abundance estimates. One situation that possibly occurred during the nutrient addition experiments is that many cells were in the Gap 1 phase and simultaneously entered the S phase, where DNA is replicated. Even though the biomass may not have increased significantly, nifH DNA copy numbers would have. It is also possible that growth rates based on laboratory cultures of diazotrophs growing on dissolved inorganic nutrients are not reflective of natural populations growing on a mix of organic and inorganic nutrients. More work is needed to determine the exact interpretation of gene copy abundances.

\section{Adaptations of diazotrophs to Fe and P stress}

PFe additions enhanced $\mathrm{N}_{2}$ fixation in Expts $\mathrm{A}$ and $\mathrm{B}$, but fixation was also elevated in dust treatments. Quantification of the nifH gene revealed increases of more than 2 orders of magnitude with Saharan dust additions. Additions of N, P, and especially Fe also resulted in elevated nifH copy numbers, depending on the diazotrophic phylotype, but these increases were not of the same magnitude as observed with dust additions. Based on the increases in diazotrophic 
phylotype abundances and $\mathrm{N}_{2}$ fixation rates with additions of Saharan dust, it appears that the chemical composition of dust is a very good match for several of the nutrients and trace metal requirements of diazotrophs.

Saharan dust contains many elements including trace metals, the most biologically important being $\mathrm{P}$ and $\mathrm{Fe}$ (Baker et al. 2006). $\mathrm{N}$ can adsorb to dust particles as $\mathrm{NO}, \mathrm{NO}_{2}$, and $\mathrm{NH}_{3}$ (Mills et al. 2004, Duce et al. 2008). Saharan dust also contains organic N, P (Mahowald et al. 2008), and C (Duarte et al. 2006). Trichodesmium spp. have genes coding for organic P utilization enzymes (e.g. alkaline phosphatase and C-P lyase), making dissolved organic $\mathrm{P}$ accessible, and have a higher affinity for organic $\mathrm{P}$ over $\mathrm{PO}_{4}$, which may give them a competitive advantage over other organisms (Sohm \& Capone 2006). However, not all diazotrophs have equal access to dissolved organic P: for example UCYN-B (Crocosphaera) does not have C-P lyase (Dyhrman et al. 2006) and was not enhanced by dust additions in the D1 treatment and only moderately enhanced in the D2 treatment. The inability of Crocosphaera to utilize phosphonates may explain the low abundances and very patchy distribution of this phylotype in the North Atlantic. Although the amount of P and Fe released during the bioassay experiments described above was at the nmol level (Mills et al. 2004), the diazotrophic community was clearly able to respond to this low level influx of nutrients.

Saharan dust is the major source of both Fe and $\mathrm{P}$ to the Atlantic Ocean providing up to $16 \mathrm{Tg} \mathrm{Fe}_{\mathrm{yr}^{-1}}$ (Jickells et al. 2005) and $1.15 \mathrm{Tg} \mathrm{P} \mathrm{yr}^{-1}$ (Mahowald et al. 2008), or 82 and $83 \%$ of the total input, respectively, and it is potentially very favorable to growth of diazotrophic organisms due to the low N:P ratio (Krishnamurthy et al. 2010). The absolute amounts of each nutrient that may be obtained from average, and even extreme, dust events are minimal (Table 3). A quick calculation shows that an average deposition of $30 \mu \mathrm{g}$ dust $\mathrm{m}^{-3}$ (Guieu et al. 2002) to a $10 \mathrm{~m}$ surface layer delivers roughly $2.6 \mathrm{nmol} \mathrm{N} \mathrm{m}{ }^{-3}, 1.0 \mathrm{nmol}$ $\mathrm{P} \mathrm{m}^{-3}$, and $21.5 \mathrm{nmol} \mathrm{Fe} \mathrm{m}{ }^{-3}$. However, if a cell or colony of cells were adept at obtaining nutrients directly from dust particles before they leached into the surface water layer, the benefits of these added nutrients in a concentrated form would be greatly increased for microorganisms inhabiting nutrientpoor, oligotrophic waters. Trichodesmium may have several mechanisms for effectively scavenging $\mathrm{Fe}$, and potentially other nutrients, from dust particles (Carpenter et al. 1991). For instance, colonies of Trichodesmium collected in the field rapidly attached to
Table 3. Estimated inputs of total $\mathrm{P}, \mathrm{Fe}$, and $\mathrm{N}$ in a $10 \mathrm{~m}$ surface layer from an average $\left(30 \mu \mathrm{g} \mathrm{m}^{-2}\right)$ and large $(100 \mu \mathrm{g}$ $\mathrm{m}^{-2}$ ) dust event (as defined by Guieu et al. 2002)

\begin{tabular}{|c|c|c|c|c|c|}
\hline & $\begin{array}{c}\text { Compo- } \\
\text { sition } \\
(\%)\end{array}$ & $\begin{array}{r}\text { Averag } \\
\text { Deposited } \\
\left(\mu \mathrm{g} \mathrm{m}^{-3}\right)\end{array}$ & $\begin{array}{l}\text { e event } \\
\text { Conc. } \\
\left(\mathrm{nmol} \mathrm{m}^{-3}\right)\end{array}$ & $\begin{array}{r}\text { Large } \\
\text { Deposited } \\
\left(\mu \mathrm{g} \mathrm{m}^{-3}\right)\end{array}$ & $\begin{array}{l}\text { event } \\
\text { Conc. } \\
\left(\mathrm{nmol} \mathrm{m}^{-3}\right)\end{array}$ \\
\hline P & $0.1^{\mathrm{a}}$ & 0.03 & 1.0 & 0.1 & 3.2 \\
\hline $\mathrm{Fe}$ & $4^{\mathrm{a}}$ & 1.2 & 21.5 & 4 & 71.6 \\
\hline $\mathrm{N}$ & $0.12^{\mathrm{b}}$ & 0.036 & 2.6 & 0.1 & 9.6 \\
\hline \multicolumn{6}{|c|}{${ }^{\mathrm{a}}$ From Guieu et al. (2002); ${ }^{\text {b }}$ from Mills et al. (2004) } \\
\hline
\end{tabular}

dust particles, and scanning electron microscopy revealed dust particles among bundles of Trichodesmium filaments (Carpenter et al. 1991). These colonies are very effective at dissolving dust and oxides (Rubin et al. 2011). Changes in Trichodesmium morphology from single filaments to large colonies upon dust addition (regardless of the Fe concentration in the media) were observed in our culture experiments (Fig. 4). Diazotrophs may also be able to access Fe through siderophores, high affinity Febinding compounds. Genes for nonribosomal peptide synthetase (NRPS) systems, which can be used to produce siderophores, are found in both the $T$. erythraeum and Crocosphaera watsonii genomes (Hopkinson \& Morel 2009). Field Trichodesmium colonies have been shown to take up siderophore-bound Fe and, interestingly, radial 'puff' colonies had higher uptake rates than lateral 'tuft' colonies (Achilles et al. 2003). It is possible that other diazotrophs may have similar strategies for acquiring $\mathrm{P}$ and $\mathrm{Fe}$ in oligotrophic environments.

\section{Saharan dust as a determinant for diazotroph distributions}

Patterns in Trichodesmium abundance have been previously correlated with dust deposition (Langlois et al. 2008, Moore et al. 2008). Moore et al. (2009) provided a well-supported argument for the correlation of Trichodesmium and Saharan dust deposition. On a transect from the North Atlantic Ocean through the South Atlantic Ocean, both the distribution of Trichodesmium and peak $\mathrm{N}_{2}$ fixation rates were aligned with maximum dissolved $\mathrm{Fe}$ and $\mathrm{Al}$ concentrations, the latter being a proxy for dust deposition, and reduced $\mathrm{P}$ concentrations. In the South Atlantic, there was a lack of Trichodesmium which correlated with decreased $\mathrm{Fe}$ and $\mathrm{Al}$ concentrations. Here

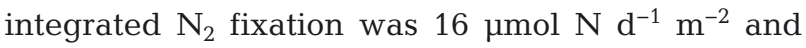
detected only in the $<20 \mu \mathrm{m}$ fraction; it is not likely to 
be attributable to Trichodesmium. This result was recently confirmed by Fernandez et al. (2010) on 2 similar transects through the North and South Atlantic during the fall and spring. Additionally, a Trichodesmium bloom off western Florida, large enough to draw-down $\mathrm{PO}_{4}$, occurred after a large deposition event (Lenes et al. 2001). Trichodesmium colony abundance at the Bermuda Atlantic TimeSeries site was positively correlated to the magnitude of dust deposition; however, fixation rates did not increase with increasing dust deposition (Orcutt et al. 2001). Clearly, in the tropical North Atlantic Ocean, evidence is mounting to support the hypothesis that the deposition of desert dust originating from the African continent is a strong determinant for the distribution of Trichodesmium.

Saharan dust may not be beneficial to all marine organisms. A set of experiments performed in the Gulf of Aqaba demonstrated that Saharan dust was toxic, probably due to $\mathrm{Cu}$ bound to the dust, to picoeukaryotes and Synechococcus, but was not toxic to Prochlorococcus (Paytan et al. 2009). However, other studies have observed significantly lower $\mathrm{Cu}$ solubility for Saharan dust over the Atlantic (Sholkovitz et al. 2010) or no changes in seawater $\mathrm{Cu}$ speciation upon addition of Saharan dust (Heller \& Croot 2011). In the bioassay experiments presented here, Saharan dust had variable effects on the picophytoplankton community (Fig. 4). Interestingly, the positive response of Synechococcus and Prochlorococcus was highest where the diazotroph response (specifically UCYN-A) was highest and decreased moving east, as did the positive response to dust of the phylotypes.

\section{Regulation of $\mathrm{N}_{2}$ fixation versus photosynthesis}

$\mathrm{N}_{2}$ fixation is an expensive process for cells, with respect to both energy and trace metal requirements. A phototrophic diazotroph requires 42 to $48 \mathrm{Fe}$ atoms for both the nitrogenase enzyme and photosynthetic machinery (Shi et al. 2007). Diazotrophs, such as Crocosphaera, that fix nitrogen during the night are able to recycle $\mathrm{Fe}$ atoms between photosynthesis and nitrogenase enzymes (Raven 2012). Others, like Trichodesmium, that carry out photosynthesis and $\mathrm{N}_{2}$ fixation simultaneously, need to find another solution. Under Fe stress, Trichodesmium cultures preferentially down-regulate $\mathrm{N}_{2}$ fixation to conserve $\mathrm{Fe}$ for photosynthesis (Shi et al. 2007, Küpper et al. 2008). It is possible that open-ocean diazotrophs are in a permanent state of Fe stress when a balance between $\mathrm{N}_{2}$ fixation and photosynthesis must be reached. Downregulation of $\mathrm{N}_{2}$ fixation in favor of photosynthesis may have occurred in the bioassay experiments and could explain the discrepancy between the increase in fixation rates and phylotype abundances. Photosynthesis may also have been preferentially upregulated over nifH expression in the culture experiment. After $60 \mathrm{~h}$, nifH expression decreased in all treatments except for the highest Fe concentration. The culture experiments also showed that Trichodesmium is able to at least partially fulfill its Fe requirements from atmospheric dust. Increases in nifH copy numbers were not higher with dust as an Fe source than that of dissolved Fe in the culture experiments compared to the field experiments, but cultured Trichodesmium is accustomed to high nutrient and $\mathrm{Fe}$ concentrations and may have been in a different physiological state than the oceanic diazotrophs. Rubin et al. (2011) also demonstrated that laboratory cultures of $T$. erythraeum were less efficient at obtaining Fe from dust particles than field communities. Only $2.4 \mathrm{nmol}$ Fe was released from the dust into media without cells during lab experiments (P. Croot unpubl.). This is one-twentieth of the amount in the YBCII media. However, Trichodesmium colonies that are able to trap dust particles can potentially scavenge more iron directly without elevating bulk solution concentrations. In fact, when placed in media with atmospheric dust as the sole Fe source, the culture survived to the end of the experiment while the $0.0 \mu \mathrm{mol} \mathrm{l}^{-1}$ Fe control culture died, indicating that Trichodesmium was able to slowly extract Fe from the dust.

\section{CONCLUSIONS}

Aeolian dust deposition has long been suspected to provide Fe to Trichodesmium colonies in the Atlantic Ocean (Carpenter et al. 1991). Results of the bioassay experiments showed that dust additions clearly affected not only Trichodesmium, but other diazotrophic phylotypes abundances as well, indicating that atmospheric dust deposition may greatly influence the distribution of various diazotrophic groups. Culture experiments with Trichodesmium grown in Fe-free media and Saharan dust showed that it is able to access and use Fe from dust. Experiments with other cultured open-ocean diazotrophs need to be performed to see if this is a characteristic of all diazotrophs. A correlation between modeled annual aeolian dust deposition and nifH phylotype abundance has been observed in the Atlantic Ocean (Lang- 
lois et al. 2008), supporting the results of the experiments presented here. Saharan dust deposition appears to play a major role in the distribution of diazotrophic organisms, and thus $\mathrm{N}_{2}$ fixation, in the Atlantic Ocean.

Acknowledgements. We thank A. Baker for providing the Saharan dust used in the laboratory experiments and $\mathrm{M}$. Davey for help with the experiments at sea and for making the flow-cytometry data available. S. Treydte performed the dust dissolution experiment. This work was funded by DFG grant RO2138/5-1 to J.L. We are very grateful to the 3 anonymous reviewers for their helpful comments and insights.

\section{LITERATURE CITED}

Achilles KM, Church TM, Wilhelm SW, Luther GW III, Hutchins DA (2003) Bioavailability of iron to Trichodesmium colonies in the western subtropical Atlantic Ocean. Limnol Oceanogr 48:2250-2255

Baker AR, Jickells TD, Witt M, Linge KL (2006) Trends in the solubility of iron, aluminium, manganese, and phosphorus in aerosol collected over the Atlantic Ocean. Mar Chem 98:43-58

> Baker AR, Weston K, Kelly SD, Voss M, Streu P, Cape JN (2007) Dry and wet deposition of nutrients from the tropical Atlantic atmosphere: links to primary productivity and nitrogen fixation. Deep-Sea Res I 54:1704-1720

Capone D, Burns J, Montoya JP, Subramaniam A and others (2005) Nitrogen fixation by Trichodesmium spp.: an important source of new nitrogen to the tropical and subtropical North Atlantic Ocean. Global Biogeochem Cycles 19:GB2024, doi:10.1029/2004GB002331

Carpenter EJ, Capone DG, Rueter JG (1991) Marine pelagic cyanobacteria: Trichodesmium and other diazotrophs. NATO ASI Ser C, Vol 362. Kluwer, Dordrecht

> Chen YB, Zehr JP, Mellon M (1996) Growth and nitrogen fixation of the diazotrophic filamentous nonheterocystous cyanobacterium Trichodesmium sp. IMS101 in defined media: evidence for a circadian rhythm. J Phycol 32: 916-923

> Church MJ, Bjoerkman KM, Karl DM, Saito MA, Zehr JP (2008) Regional distribution of nitrogen-fixing bacteria in the Pacific Ocean. Limnol Oceanogr 53:63-77

> Croot P, Streu P, Baker A (2004) Short residence time for iron in surface seawater impacted by atmospheric dry deposition from Saharan dust events. Geophys Res Lett 31:L23S08, doi:10.1029/2004GL020153

> Davey M, Tarran GA, Mills MM, Ridame C, Geider RJ, La Roche J (2008) Nutrient limitation of picophytoplankton photosynthesis and growth in the tropical North Atlantic. Limnol Oceanogr 53:1722-1733

> Duarte CM, Dachs J, Llabres M, Alonso-Laita P and others (2006) Aerosol inputs enhance new production in the subtropical Northeast Atlantic. J Geophys Res 111:G04006, doi:10.1029/2005JG000140

> Duce RA, La Roche J, Altieri K, Arrigo KR and others (2008) Impacts of atmospheric anthropogenic nitrogen on the open ocean. Science 320:893-897

> Dyhrman ST, Chappell PD, Haley ST, Moffett JW, Orchard ED, Waterbury JB, Webb EA (2006) Phosphonate utilization by the globally important marine diazotroph Tricho- desmium. Nature 439:68-71

Falkowski PG (1997) Evolution of the nitrogen cycle and its influence on the biological sequestration of $\mathrm{CO}_{2}$ in the ocean. Nature 387:272-275

- Fernandez A, Mourino-Carballido B, Bode A, Varela MM, Maranon E (2010) Latitudinal distribution of Trichodesmium spp. and $\mathrm{N}_{2}$ fixation in the Atlantic Ocean. Biogeosci Discuss 7:2195-2225

> Graziano LM, Geider RJ, Li WKW, Olaizola M (1996) Nitrogen limitation of North Atlantic phytoplankton: analysis of physiological condition in nutrient enrichment experiments. Aquat Microb Ecol 11:53-64

> Guieu C, Loye-Pilot MD, Ridame C, Thomas C (2002) Chemical characterization of the Saharan dust end-member: some biogeochemical implications for the western Mediterranean Sea. J Geophys Res 107:4258, doi:10.1029/ 2001JD000582

> Heller MI, Croot P (2011) Superoxide decay as a probe for speciation changes during dust dissolution in tropical Atlantic surface waters near Cape Verde. Mar Chem 126:37-55

> Hopkinson BM, Morel FMM (2009) The role of siderophores in iron acquisition by photosynthetic marine microorganisms. Biometals 22:659-669

> Jickells TD, An ZS, Andersen KK, Baker AR and others (2005) Global iron connections between desert dust, ocean biogeochemistry, and climate. Science 308:67-71

Karl D, Michaels A, Bergman B, Capone D and others (2002) Dinitrogen fixation in the world's oceans. Biogeochemistry 57:47-98

- Krishnamurthy A, Moore JK, Mahowald N, Luo C, Zender C (2010) Impacts of atmospheric nutrient inputs on marine biogeochemistry. J Geophys Res 115:G01006, doi:10.1029/ 2009JG001115

> Küpper H, Setlik I, Seibert S, Prasil O and others (2008) Iron limitation in the marine cyanobacterium Trichodesmium reveals new insights into regulation of photosynthesis and nitrogen fixation. New Phytol 179:784-798

Kustka A, Sanudo-Wilhelmy S, Carpenter EJ, Capone DG, Raven JA (2003) A revised estimate of the iron use efficiency of nitrogen fixation, with special reference to the marine cyanobacterium Trichodesmium spp. (Cyanophyta). J Phycol 39:12-25

Langlois RJ, La Roche J, Raab PA (2005) Diazotrophic diversity and distribution in the tropical and subtropical Atlantic Ocean. Appl Environ Microbiol 71:7910-7919

> Langlois RJ, Huemmer D, La Roche J (2008) Abundances and distributions of the dominant nifH phylotypes in the northern Atlantic Ocean. Appl Environ Microbiol 74: 1922-1931

> Lenes JM, Darrow BP, Cattrall Cl, Heil CA and others (2001) Iron fertilization and the Trichodesmium response on the West Florida shelf. Limnol Oceanogr 46:1261-1277

Lenes JM, Walsh JJ, Otis DB, Carder KL (2005) Iron fertilization of Trichodesmium off the west coast of Barbados: a one-dimensional numerical model. Deep-Sea Res I 52: 1021-1041

> Mahaffey C, Michaels AF, Capone D (2005) The conundrum of marine $\mathrm{N}_{2}$ fixation. Am J Sci 305:546-595

Mahowald N, Jickells TD, Baker A, Artaxo P and others (2008) Global distributions of atmospheric phosphorus sources, concentration and deposition rates, and anthropogenic impacts. Global Biogeochem Cycles 22:GB4026, doi:10.1029/2008GB003240

Mather RL, Reynolds SE, Wolff GA, Williams RG and others 
(2008) Phosphorus cycling in the North and South Atlantic Ocean subtropical gyres. Nat Geosci 1:439-443

Mills MM, Ridame C, Davey M, La Roche J, Geider RJ (2004) Iron and phosphorus co-limit nitrogen fixation in the eastern tropical North Atlantic. Nature 429:292-294

Mohr W, Großkopf T, Wallace DWR, LaRoche J (2010) Methodological underestimation of oceanic nitrogen fixation rates. PLoS ONE 5:e12583

Moisander $\mathrm{PH}$, Belnart RA, Hewson I White AE and others (2010) Unicellular cyanobacterial distributions broaden the oceanic $\mathrm{N}_{2}$ fixation domain. Science 327:1512-1514

Moore CM, Mills M, Milne A, Langlois RJ and others (2006) Iron limits primary productivity during spring bloom development in the central North Atlantic. Glob Change Biol 12:626-634

Moore CM, Mills M, Langlois RJ, Milne A, Achterberg EP, La Roche J, Geider R (2008) Relative influence of nitrogen and phosphorus availability on phytoplankton physiology and productivity in the oligotrophic sub-tropical North Atlantic Ocean. Limnol Oceanogr 53:291-305

Moore CM, Mills MM, Achterberg EP, Geider R and others (2009) Large-scale distribution of Atlantic nitrogen fixation controlled by iron availability. Nat Geosci 2:867-871

Orcutt KM, Lipschulz F, Gundersen K, Arimoto R, Michaels AF, Knap AH, Gallon JR (2001) A seasonal study of the significance of $\mathrm{N}_{2}$ fixation by Trichodesmium spp. at the Bermuda Atlantic Time-Series study (BATS) site. DeepSea Res II 48:1583-1608

Paytan A, Mackey KRM, Chen Y, Lima ID and others (2009) Toxicity of atmospheric aerosols on marine phytoplankton. Proc Natl Acad Sci USA 106:4601-4605

Raven JA (2012) Protein turnover and plant RNA and phosphorus requirements in relation to nitrogen fixation. Plant Sci 188-189:25-35

Ridame C, Guieu C (2002) Saharan input of phosphate to the

Editorial responsibility: Katherine Richardson,

Copenhagen, Denmark oligotrophic water of the open western Mediterranean Sea. Limnol Oceanogr 47:856-869

- Ridame C, Le Moal M, Guieu C, Ternon E, Biegala IC, L'Helguen S, Pujo-Pay M (2011) Nutrient control of $\mathrm{N}_{2}$ fixation in the oligotrophic Mediterranean Sea and the impact of Saharan dust events. Biogeosciences 8:2773-2783

Rubin M, Berman-Frank I, Shaked Y (2011) Dust- and mineral-iron utilization by the marine dinitrogen-fixer Trichodesmium. Nat Geosci 4:529-534

Shi T, Sun Y, Falkowski P (2007) Effects of iron limitation on the expression of metabolic genes in the marine cyanobacterium Trichodesmium erythraeum IMS101. Environ Microbiol 9:2945-2956

Shi Z, Krom MD, Bonneville S, Baker AR and others (2011) Influence of chemical weathering and aging of iron oxides on the potential iron solubility of Saharan dust during simulated atmospheric processing. Global Biogeochem Cycles 25:GB2010, doi:10.1029/2010GB003837

Sholkovitz ER, Sedwick PN, Church TM (2010) On the fractional solubility of copper in marine aerosols: toxicity of aeolian copper revisited. Geophys Res Lett 37:L20601, doi:10.1029/2010GL044817

> Sohm JA, Capone DG (2006) Phosphorus dynamics of the tropical and subtropical north Atlantic: Trichodesmium spp. versus bulk plankton. Mar Ecol Prog Ser 317:21-28

Tyrrell T, Maranon E, Poulton AJ, Bowie AR, Harbour DS, Woodward EMS (2003) Large-scale latitudinal distribution of Trichodesmium spp. in the Atlantic Ocean. J Plankton Res 25:405-416

> Wu J, Sunda W, Boyle EA, Karl DM (2000) Phosphate depletion in the western North Atlantic Ocean. Science 289: 759-762

Zani S, Mellon MT, Collier JL, Zehr JP (2000) Expression of nifH genes in natural microbial assemblages in Lake George, New York, detected by reverse transcriptase PCR. Appl Environ Microbiol 66:3119-3124

Submitted: February 20, 2012; Accepted: October 11, 2012

Proofs received from author(s): November 30, 2012 